\title{
The Value of Russian Religious Philosophy of XIX - Beginning of XX Century in the Spiritual and Moral Education of Young People
}

\author{
P. Andreevich Ponomarev ${ }^{1}$
}

\section{A. Mihaylovich Rudenko ${ }^{1}$}

\author{
S. Ivanovich Samygin ${ }^{2}$ \\ ${ }^{1}$ Don State Technical University, ${ }^{2}$ Rostov State University of Economics \\ Email: ponomarev_p@mail.ru
}

\section{Doi:10.5901/mjss.2015.v6n2s1p275}

\section{Abstract}

\begin{abstract}
This article is about the national peculiarity of Russian religious philosophy of XIX -the beginning of XX centuries. In this article were presented multi-faceted problems of human existence, and introspection of Russian thinkers is focused on the spiritual aspect. In this article problem - solving of socio-anthropological and moral-religious problematic is shown by Russian religious philosophers. Important is the analyses and interpretation of the idea of catholicity suggested by Russian religious philosophers. The analysis of the concept of unity which is the further evolution of the doctrine of the unity is realizing. It is noted the unity as the inner essence of life is inherent in human being and God. The path to unity is through love. Identity conception and its relationship with society are presented by Russian thinkers. The idea of unity advanced by Russian religious philosophy thinkers is considered as moral and axiological unity of freedom, grace and love. It is concluded that the education of "solid-hearted human being" is possible only on the bases of "the integrity of the spirit". It is pointed that the moral aspect in human is central and determinative state of other spheres of the spirit.
\end{abstract}

Keywords: catholicity, unity, entirety, personality, society, cosmism, young people;

\section{Introduction}

The Russian philosophy in spite of the great influence of Western philosophical thought developed in original way. Including the discrepancy of historical and cultural development of Russia, philosophical thought constructively refined inventiveness of Western philosophy and reinterpreted it with reference to the tasks and problems of Russian reality. Russian thinkers created a value system grounded the aims and ideals which were alternative with reference to those that existed in Western philosophical thought.

According to the most researchers after long period of preparatory phase of formation the period of development of independent national philosophy begins since the late 30-ies of XIX century. The expanding of the scientific understanding of the distinctiveness of Russian religious philosophy of late XIX-early XX centuries is the main aim of this article.

It should be pointed out that the characteristic feature of Russian religious philosophy was the fact that in the focus of philosophical reflection were problems of human existence, life in all its manifestations, and the close attention was attended its spiritual aspects. The identity of Russian philosophy was in tendency of Russian thinkers to understand deeply the human inward and his spiritual and moral aspirations based on their interpretation of Genesis. In the focus of philosophical reflections of Russian philosophers were the problems of aim and meaning of human existence which were observed in close connection with idea of the necessity of the development of human spirituality. Unanimous recognition of spiritual and moral perfection of human as the aim and meaning of human existence was in focus of philosophical reflections of Russian philosophers. Researchers of the history of Russian philosophy (Berdiaev N. A., Shpet G. G., Loskii N. O., Losev A. F.) accentuated that Western rationalism was not the characteristic of Russian philosophizing it was based on the Orthodox theory. Russian thinkers outrun the hermeneutic phenomenological interpretation of Christianity recognizing it as the basis of humanistic worldview.

The Russian thinkers highlight socio-anthropological and moral and religious issues and unlike in Western philosophy pay less attention to issues of gnoseology. Russian religious philosophers strive to solve problems of social injustice, eradication of evil and other social vices by ideological tools among which dominates morality. They condemn 
selfish individualism and call to catholicity, mutual assistance. From the very beginning the idea of catholicity of social consciousness while explaining social phenomena and processes is the leading. They maintain that only within united (organic) whole "I" of individual can be realized and generally spiritual, moral and social harmony can be reached. They reject violent methods of solving the problem of social rearrangement.

In the process of development of Russian philosophy two schools are generated.

The first one expressed the desire for basing of culture of Russian identity due to the historical development of the Russian state (Slavophiles). The second is longed for accustoming Russia to the process of development of European culture (Westerners). For the first time in their work the Slavophiles are able to convey the uniqueness of the development of the Russian state and its culture and to show the ways of spiritual self-determination of the Russian people. Slavophiles's theory show the ways of ideal social rearrangement and has got pronounced educational orientation. In contrast to values of rationalism and individualism which are dominating in the European philosophical tradition, Slavophiles suggest an ideal of an integral personality and соборные начала in Russian culture.

The leading method used in the article is system and historico-logical methods, analysis, synthesis, integration of certain theses in the theory.

\section{The Theory of Catholicity and Unity in Russian Religious Philosophy}

Russian thinkers put forward the idea of catholicity as influential. This idea embodies socio-spiritual unity of people based on freedom, love and faith. Khomyakov A. S. who first introduces the notion of catholicity considers it as "disciplinary matrix" of Russian. According to Khomyakov the catholicity introduce the idea of "free unity of foundations of the Church in case of united search of the way to rescue, unity based on unanimous love of Christ and heavenly goodness".

It is typical, that while examining the catholicity, first of all as ecclesiastical, Khomyakov gives it meaning also in other aspects. First of all it is fundamental theory of social arrangement. There are elements of catholicity in every sustainable society. Secondly the catholicity is regarded as internal consistency of all spiritual forces: senses, intellect, organs of sense, emotions and also overcoming of separateness of the soul into subject and object, which is reached with the help of love (Khomyakov, A.S., 1982).

Khomyakov A. S. and Kireevsky I. V. see in the catholicity true overall sociality which is built on a voluntary basis. The catholicity as an attribute of specific Russian social and cultural life is appeared as preimage of Reign of God, germ of "free ecclesiasticism" which is come to take the place of "material compulsion" social structure (Modern Philosophical Dictionary, 1996).

It should be noted that the idea of catholicity while becoming the base of Russian religious literature nevertheless receives different interpretations. So, Akskakov K. S. identified catholicity with community. Solovev V. S. uses the idea of catholicity while creating the theory of unity. Leaning on fundamentals of the theory of unity Trubetskoy S. N. understands catholicity as coincidence of religious, moral and social principles and considers it to be most essential characteristic of consciousness.

Bulgakov S. and Florensky P. while examining the catholicity in Church doctrinal context see in it universe, unified life in unified truth. At the same time Florensky as well as Khomyakov finds in catho- personality not reality but a vector as an ideal for Church members (The World Encyclopedia of Philosophy, 2001).

While characterizing the ideas of catholicity it can be noted that:

- $\quad$ first of all, the notion catholicity includes idea of harmonically solid character of human existence. That solidity is treated as primacy of sociality in relation to individual;

- secondly, harmony and solidity determined free character of spiritual unity of people in Church as the highest expression of sociality;

- thirdly, some doctrines of catholicity are determined by specific character of Russian social and cultural life, " on which the historical mission of Russia in realizing transcendental, providential idea of history are grounded" (Modern Philosophical Dictionary, 1996).

Important for Russian religious philosophers is idea of "unity which is the further development and generalization of the Slavophiles's theory of catholicity. In Russian philosophy four systems of unity can be distinguished: sociological, monodualistical, monopluralistical, symbolical. The most developed is the sophiological system of unity, which is proposed by Solovev V.S., in which God is regarded as ideal absolute and aim of world development. The notion "Sophia" - the symbol of divine wisdom, embodies required state of world, its preimage and is the mediator between the divine sphere and the real world.

Solovev V. S. understands unity in three aspects:

- gnoseologically - as the unity of three kinds of knowledge: empirical (science), reasonable (philosophy) and 
mystical (religious contemplation) which is reached not in cognitive activity, but with the help of intuition, faith;

- sociopractical - the unity of the state, society, Church which is based on the fusion of Catholicism, Protestantism and Orthodoxy;

- $\quad$ axiological - the unity of three absolute values: kindness, truth, beauty under condition of the primacy of the kindness(Solovyov, B.C., 1988).

Solovev V. S. calls true or positive the unity "in which the common exists not due to all others or in prejudice of others but in favour of others... true unity retains and strengthens its elements, realizing in it as completeness of existence" (Solovyov, B.C., 1988). The unity as inner nature of life is inherent in human being, as well as in God. Human being can "want" it as well as "don't want". So, man is free to choose his story and fortune. Human history is a process of human reaching the God which results in occurrence of "Humanity containing divinity " who turns to be the co-Creator in cases of reorganization of existence, establishing harmony of the human spirit, society, nature. Solovev writes: "The liberation of human consciousness and the gradual spiritualization of man through internal development of the divine form the actual history of humanity".

Kindness which through the culture should improve the existence in process of reaching the unity is very important according to Solovev. He sees the way of overcoming the imperfections of life and reaching the victory of truth, kindness and beauty over the vices through "humanity containing divinity process". He sees the essence of social progress in the growth of the spiritual influence of Christianity and maintaining of such Christian values as mercy, compassion and etc. in the public consciousness. According to Solovev the aim of humanity is "arranging of complete organization" or "integral life" which are possible only by reaching the spiritual state of all people. "Integral life" means: at first, society social organization, internally harmonious and in harmony with nature; secondly, harmony of man's inner world, his spirit.

Solovev considered the evil in man as the main obstacle on the way to positive unity:" this is unique self-affirmation or selfishness... this is the opposition of oneself to others and practical negation of those others...". Solovev also shows the way of evil overcoming. He is sure that solidity ("unity") of human can be possible only with a special condition of his soul - love. In accordance with Christian doctrine where love is God himself the thinker claimed that love is in whole Universe and has a cosmic nature. Love to God and to people is a necessary condition for the completeness and integrity of human life. The thinker thinks that "the meaning of human love is the justification and salvation of individuality through the sacrifice of selfishness", inner recognition of other's truth, its absoluteness. Love helps to recognize others and our dignity, teaches us to see in other people an absolute value. It suggests that "we treat the social world and the environment as a real living being with whom we never merge to indifference, and are in very close and full cooperation" (Solovyov, B.C., 1990). Love is incompatible with the social evil and should lead both an individual and all humanity to "perfect kindness".

\section{The Idea of Solidity in Slavophiles's Works}

Methodologically important is the idea of solidity which is putted forward by Slavophiles's. This idea determines spiritual and holistic human existence. "Solidity" is regarded in moral and axiological context as the unity of freedom, grace and love, and is interpreted:

- gnoseologically - in theory of live and integral knowledge;

- doctrinally - as catholicity;

- anthropologically - through the principle of "holistic spirit";

- $\quad$ historically - as the provisions of the common ethical foundations of "religions freedom" (Yarkina, T.F., 1996).

The search of "that internal root of comprehension where all the individual forces merge into one alive and solid vision of the mind", brings to the formulation of "spirit solidity", on the bases of which is put forward the idea of educating of "solid person", in which "the mind and will, and feeling, and conscience, the beautiful and the true, amazing and desirable, fair, and merciful, and the entire volume of the minds merge into one living unity" (Kireyevsky, I.V., 1996).

Creativity and work of Kirievsky I. V., Khomyakov A. S., Shevirev S. P. and other representatives of intellectuals stimulate increase of interest to the Russian Orthodox traditional education, in which they singled out such features as originality, openness to the foreign world. In their opinion the educational process should be based on religion, morality and love for the neighbour, i.e. on the Orthodox and universal spiritual values. Slavophiles see the aim of personal development in "picking up" the powers of the soul, the restoration of original ontological relationship with God. Shevyrev S. P., the head of the Department of pedagogics at the University of Moscow, considered "spiritual elevation" to be the main task of education. He maintains the idea of developing of the "inner man", in the Russian children, in which there is a unity of universal and national, Russian beginning (History of Education, A.I. Piskunov, 1988). On the basis of beliefs about the identity of the historical path of the Russian people Kireevsky believes that the Russian mind and character in 
contrast to the European is characterized by integrity, the unity of reason and morality. He believes that the desire "for existence solidity of internal and external, public and private, speculative and practical, artificial and moral" is the specific features of the Russian education (Kireyevsky, I.V., 1861). He believed that Russian Enlightenment is organically inherent in the optimal combination of reason and faith, which promotes natural attitude of the Russian people to nature society and the world, where "the creation of each individual creates all, and each person is breathing the life of all other" (Salnikov, V.P., Y.A. Sandulov, H.S. Gutseriev and I.I. Kalnoy, 2010). Khomyakov A. S. thinks that the solidity of individual is conditioned by the spirit, which is autonomous and independent from any rational reflection or from social influence. (Khomyakov, A.S., 1982).

According to him, solidity of the person is realized by the interaction of the central and peripheral powers of the soul which has hierarchical structure. All our strength of spirit should be placed around the central forces of Godkind mind.

Khomyakov A. is sure that people are united by internal communication, which is manifested in all spheres of the spirit and activity of the individual. According to him, social control over the individual is violence, as it substitutes the internal communication for external. Kireevsky, who made a great contribution to the creation of the concept "holistic spirit" believes that the man's core is his spiritual sphere. Only "solid person" can have spiritual culture on his way of achieving "solid knowledge" about reality. Kireevsky sees a way to regain solidity... to domination of "internal focus" in us in "the gathering of forces of the soul." For reaching his focus, restoring the original ontological relationship with God "work needs, spiritual work on yourselves needs, hard work on the "natural" inclinations of man".

Kireevsky emphasizes that working on his spiritual dispensation, man "is not acting alone and not for himself only, he does the common activity of all Church" and here expresses an interesting thought: "All that is essential in the soul of man grows in him publicly". Thus the true essence of man can be appeared only catholicitically.

The moral sphere plays the main role in human being, on "health" of which depends the state of other spheres of the spirit. According to Kirievsky "moral health... is lost where there is a struggle with a "natural" separation of spiritual forces". He thinks that the West is spiritually stuck, because the "enlightenment which is based on the development of the broken forces of the mind has no significant relationship to the moral construction of man" (The World Encyclopedia of Philosophy, 2001).

Slavophiles tries to overcome the contradiction between mind and faith. They believe that the mind divorced from faith and love leads to moral oblivion, knowledge must be closely connected with faith and morals, otherwise it can be dangerous. Full and highest truth can't be grasped only by means of reason and science. True and complete knowledge is possible only with holistic spirit, based on faith and religion.

3. Russian thinkers approach towards the comprehension of the personality and its relationships with the society.

Russia religious philosophers paid great attention to the personality and its relationships with the society.

A. Homyakov considers a personality to be the goal. Society is believed to be the means for the highest prosperity of one's personality. In his opinion, moral value of personality despite its social and other characteristic features is the value of the commonwealth with its spheres of spiritual life regulated according to Christian values.

Unlike I. Kang proclaiming human rationality to be the base of live value and personal dignity, A. Homyakov believes living spirituality (compassion, will, sympathy, awe of the Supreme, love and intellect including) to be the assessment criterion of the personality. Personal dignity is not define by position in society. (Khomyakov, A.S., 1982).

According to B.S. Soloviov personality is a goal itself and can't be estimated as a way of reaching the so called "common weal" (the weal of most people) (Solovyov, B.C., 1988). Declaring personality to be the supreme value, N.A. Berdyaev considers it to be a spiritual formation, quintessence of divine quality in a human. Personality is "image and divine resemblance in a human... Personality can't be judged from biological, psychological and sociological point of view. Personality is spiritual and presupposes the existence of the spiritual world". Personality is not a substance, it is a creative act. In the thinker's opinion the process of creative self-structuring aiming at human achieving goodlikeness is the main value of existence. According to Berdyaev personality do not exist if there is no relation to other individuals, to the God personality and to the people community. He believes personality "to be a moral principle mainly. It determines each value estimation" (Berdyaev, N.A., 1993). The mystery of personality is in its originality, uniqueness and incomparability.

According to Frank personality is an egoism. It faces supreme, spiritual, objectively significant powers and as the same time is imbued with them and represents them. Personality always expresses itself in its absolute uniqueness, irreplaceability, originality. It is the only motive power of social life (Frank, S.L., 1992).

Lossky supposes personality to possess free will and creative potential. He believes personality to be the base of existence, gives ontological substantiation of its freedom and immortality. In his opinion, personality is the central ontological element of the world (Lossky, N.O., 1994). 
L.P. Karsavin's interpretation is also of high interest. Unlike European thinkers proclaiming personality to be a selfsufficient social atom, he introduces the concept of "symphonic personality", expressing the intercommunication of variety, correlation and interdependence of a single whole. According to Karsavin the world is a united symphonic personality including hierarchic unity of countless symphonic personalities of all kind. Theoretically personality is a perfect all-constant and all-spatial unity. The objective reality existence is submitted to unity and trinity principles. In accordance to that the personal existence appears to be concluded in three dynamically changing forms: original unity, selfsegregation, self-reunion. "Personality "itself in itself" is segregated into some static and conscious essence calling "I", "my" and some essence detected, explored and learnt by that "I"-identity. However the moments of past in reduced form still remain in remembrance. Thus the reunion takes place, however the degree of personality unity now is different from what it was at the beginning. That is what makes the difference between imperfect ("acquired"') and perfect personality existent.

Pointing out personal nature of existence, Karsavin emphasizes on social (symphonic) personality, realizing itself in human personalities. There are a lot of social personalities characterizing by their own degree of perfection, "idea", specific quality. Nation, culture, humanity, etc. belong to social personalities, "acquired" unities. Marking out the fundamental role of personality trinity principle Karsavin states: "United symphonic and social personality reflects its Trininy-hypostasis essence" (Novikov, A.I., 1998).

According to L.P. Karsavin doctrine symphonic personality is the same as congregational identity. In thinker's opinion an individual becomes a personality only by his correlating with his family, estate, class, the mankind. The main goal of each individual is in realization its supreme symphonic personality. L.P. Karsavin believes it to be possible to reach the unity by "refusing all "one's" and self-denying for other's sake, voluntary sacrificing, devoting" (Karsavin, L.P., 1995).

Studying personality-social relations Russian thinkers point out society not to form personality, vice versa. Personality forms social relations. While moral self-perfecting not only an individual but also the society must be included. Person must subordinate the society to the extent it responds to ideals of moral good (B.S. Solovyov, 1988).

N.A. Berdyaev proclaims personality to be of absolute priority comparing with the society. He believes the society to be a part (an aspect) of personality. He supposed personality to be of more value than society, nation or state. In his opinion the supreme type of society is there individual is considered to be the greatest value and is respected as an immortal being.

P. Florensky's interpretation of the role of culture in social life of community is also valuable. In his opinion the world including the culture development subordinate to the law of entropy. According to it the Chaos is spreading in all spheres of the Universe including human history and spiritual life. Culture stand against the Chaos with Logos as its constructive, rational base. Like Berdyaev Florensky believes that without spiritual standards human society degrades and collapses. And the same time he points out that inspirituality of culture leads to injurious destruction of the nature, spiritless formalization of art and science (Novikov, A.I., 1998). The events of XX century proved Florensky's supposition.

\section{Moral Problems in Russian Religious Culture}

Problems of morality judging from ethical Orthodox doctrine's point of view prominently figure in Russian religious philosophers' works.

They believes moral standard to be topping in individual and social existence. Russian thinkers pay particular attention to ethic problems. Thus V.V. Zenkovsky states: "Russian philosophy... is mostly occupied with the problem of a man, his fortune and destiny, sense and aims of the history. First of all it appears in the extent of moral aim domination: this is the most efficient and constructive source of Russian philosophizing. That topping role of morality expressed by Lev Tolstoy in his works could be found almost in any Russian writer's work..." (Zenkovsky, V.V., 1999).

Like V.V. Zenkovsky, I.O. Lossky states about moral orientation of Russian philosophy the following: "in Russia philosophy development ethics plays a very significant part" (Lossky, H.O., 1991).

In philosophical works of F. M. Dostoevsky and L. N. Tolstoy moral and ethical problems are of great significance. Doctrines of Slavophiles F. M. Dostoevsky and L. N. Tolstoy were an important prerequisite to the co called "Russian spiritual Renascence" occurrence (the end of XIX - the beginning of XX century). Its appearance was due to attempt to find a new way of understanding the role of religion in spiritual life of society. Works of V. S. Soloviev, N. A. Berdyaev, S. N. Bulgakov, V. V. Zenkovsky, I. O. Lossky, I. A. Ilyin, C. J. Frank, V. V. Rozanov, L. I. Shestov, L. P. Karsavin, P. A. Florensky and other philosophers belong to that period. From the point of Christian anthropology they tried to combine the achievements of native culture and Orthodox humanistic traditions.

Ethic introspection of Russian philosophers bases on ideas of divine origin of morality, religious and spirituals 
common to all mankind unity, moral dominion of a person. Problems of morality are deeply and exhaustively studied at $\mathrm{V}$. S. Soloviev's work called "Justification of the Good or Moral Philosophy". Here the thinker points out that a human being is a moral being with three moral qualities (sense of shame, compassion and the sense of awe) as a base of his morality. Moral meaning of a human's life is to serve for Good. The philosopher appeals to respect "moral dignity of a person", its right to develop its positive potential. He also proclaims equal moral value of each human notwithstanding their individual particularities. According to Soloviev, spiritless is the main threaten for human morality. Destroying the morality it deprives human life of its human essence and subordinates it to practicability and need.

Solving the problem of morality Russian religious philosophers oppose the ethics of law to prosperity and freedom. They believe the ethics of law to be inferior for it proclaims the abstract and formal standards of good without considering person's individuality and personal inner world. The absolutization of the ethics of law involves decreasing of formal dictatorship of society and public opinion over spiritual life of a human being, the freedom of his moral evaluation. Russian thinkers believe the awakening of personal moral responsibility to be way of overcoming the social domination in the sphere of morality (Solovyov, B.C., 1988).

"The ethics of creation" (N. A. Berdyaev and L. S. Frank) is an original theoretical addition to contradiction between the law and prosperity conception. In this conception creativity is supposed to be the main way of solving moral problems. While doing that a person should make its own decision, make moral discoveries, create a new good. Berdyaev states that moral life should be a constant free and impassioned creativity, constant youth and spiritual chastity. Person should constantly defend its firstlingness, primordiality, purity of moral conscience and moral thought, withstand static archaic collective moral conscience and thought (Nekrasova, E.H., 1997). Moral development of a man is impossible in isolation from other people. It can be only common. Frank believes genuine God's will performance to be possible only in a form of boundless creation. (Frank, S.L., 1956).

Morality is studied by Russian thinkers only in close connection with the problem of personal freedom. N. A. Berdyaev connects the definition of freedom with the definition of spirituality, considering freedom to be an ontological substance of existence and indentifying it with the essence of a human being. Despite some differences in world outlook's principles Russian philosophers have a common definition of freedom. Thus B.S. Soloviov defines it as an activity of a person which "voluntarily rejects his will". N. A. Berdyaev defines freedom as "voluntary rejection of willfulness". According to Berdyaev the definition of freedom means responsibility for oneself and personal deeds. Freedom means independent life where personal dignity is proclaimed. Such a freedom resulting only from inner efforts. One can rely on no culture, state or society while self-developing. Berdyaev points out that refusing freedom modern "mass" person assigns moral responsibility on his family, class, nationality, profession, party, religion and barely distinguish personal responsibility (Berdyaev, N.A., 1993).

\section{The Ideological Doctrine of Russian Philosophers-Cosmists}

Original phenomenon of Russian philosophy of the end of XIX - the beginning of XX centuries was the so called "cosmism". In the work of philosophers-cosmists (N.F. Fedorov, V.I. Vernadsky, A.L. Chizhevsky, K.E. Tsiolkovsky) there were further enrichment and development of the idea of catholicity and unity. Characteristic features of the works of philosophers-cosmists were the recognition of deep, close relationship of man with the cosmos, the Earth with the Universe, the consideration of these issues from the perspective of spirituality and morality, which is of great interest for our study. Ethical orientation of cosmists' doctrine consists in the problem of overcoming the Evil on a cosmic scale. This problem is the central one of the whole conception.

N.F. Fedorov is known as a founder of Russian cosmism. His teaching is of highest morality and humaneness. His philosophical conception called "The philosophy of common action" postulates the idea of nature regulation and control over its elements. The main aim according to this conception is to achieve the immortality, to resurrect the dead ancestors and to settle the newly revived all over the Universe by common human efforts. That is the main moral duty of each "human sons and daughters" to dead ancestors and the only way to overcome the greatest evil existed - the death itself.

Love, according to N.F. Fedorov, is the only method to erase the human imperfection and his mortality. The thinker supposes that the philosophy of common action helps to detect the aim, the moral guideline and the meaning of life.

Despite the utopianism of N.F. Fedorov's teaching, his concept of the necessity of unification and co-operation of all people and all nations in nature control, cosmos developing, environmental problems solution is still of highest urgency and moral importance in solving global problems of the humanity.

K.E. Tsiolkovsky has a new view of "Human and Cosmos" philosophical problem. His philosophy is panethical. He believes the Universe to obey cosmic ethics. In accordance with basic ethical principle of Cosmos the total amount of 
ecumenical sufferings, evil and injustice should be steadily decreased by the result of purposeful work of the supreme intellect.

Studying the problems of aim and meaning of life, its immortality, Tsiolkovsky points out that being a cosmic creature it is appropriate for a human to seek for happiness and universal good, self-perfection which not only determinates the goal of his temporary life, but also his immortality (Introduction to Russian philosophy, 1995). Tsiolkovsky believes that social life of the humanity must develop in accordance with the new cosmic ethics.

K.E. Tsiolkovsky's cosmic ethics with mutual responsibility of all moral beings as its basis serves as a solid guidebook for the humanity for its earth's and cosmic existence and as a reference point in overcoming natural and social cataclysms.

The V.I. Vernadsky's doctrine focuses on the idea of cosmic origin of terrestrial life, origin of the biosphere and its gradually transformation into the noosphere. The thinker points out the special role of a human in the biosphere and cosmos vital activity and his increasing responsibility for all what happens on the Earth and in the Space. As a result of the biosphere having transformed into the noosphere "the constantly increasing role of a human mind (consciousness) and human efforts guided by it becomes apparent" (Works of BIOGELGEOCHEM AS USSR, 1980 and Воденко, К.В., and Самыгин С.И., 2015). V.I. Vernadsky marks it out that it is possible to reach the noosphere (the sphere of intellect) only by co-operating all human efforts. The statement of the scientist about the precondition required for further human's mind into cosmic power transformation not only by the science but also by the spiritual sphere perfecting is very important for our research.

A.L. Chizhevsky is one of the first philosophers-cosmists who gave a scientific substantiation of biological and social terrestrial life and cosmic changes interdependence. In particular he ascertains the influence of solar activity on the biosphere vital activity, such as, for example, animal migration, epidemic spreading and people mental state also. According to A.L. Chizhevsky, social processes are also determined by solar activity. The scientists believes that by forecasting the oscillations of solar activity it is possible to predict the undesirable phenomena and their consequences for the bio- and social spheres and take required precautions for their neutralization.

Marking out the continuous interdependence of cosmic and terrestrial lives, A.L. Chizhevsky believes the human achievement of the high intellectual level of development and moral perfection to be the exact way of harmony reaching. He sees the human greatness in "the greatness of his spirit" (The World Encyclopedia of Philosophy, 2001), which is of high interconnection with moral standards. Redemption of a near-by and love for him are considered here to be the supreme ones.

Important part in the philosophers-cosmists ideology belongs to the idea of active evolution. Russian thinkers believe the nature and a human to be interconnected. They proclaim them to be equivalent components of a single whole called the Universe. According to them, the nature possesses subjectivity and its unique ego, like a human being.

They believe the human in constant process of development to be an organic part of a cosmic unity and a reorganizer of the Universe and personal nature due to his active creative potential at the same time. Exactly the creative-constructive and active potential of a human being cause the transfer to the constructive stage of the world development: "To cut it short one observes the expansion of conscious spiritual energy rights, the material spirit control, the world and a human spirituality... The cosmists managed to combine the care for the whole (the Earth, the biosphere, the cosmos) with the deepest requests of the highest value - with the requests of an each concrete human being" (Воденко, К.В., and Самыгин С.И., 2015).

The philosopher-cosmists consider the united co-evolutional process to be an interdependent development of elements of natural (cosmic) and anthroposocial character. The process of nature transformation is accompanied by searching for ideal social organization: the society of "psychocracy" type (Fedorov), of "theocracy" type (Berdyaev), of "cosmocracy" type (Muravev), forming of the pneumatosphere (Florensky), the anthroposphere (Holodny), the noosphere (Vernadsky) (The World Encyclopedia of Philosophy, 2001).

One sees the contribution of Russian thinkers-cosmists in proposing the alternative doctrine of harmonious hierarchical system of relationships of a Human and the Cosmos ("cognation - catholicity - unity - sophy - common activity - noosphere"), which based on interconnection and interdependence of its component elements in contrast to previously dominated West European conception of anthropocentrism proclaiming the confrontation between a Human (possessing ego-identity) and the Nature (possessing no ego-identity). The human and nature cognation makes for the catholicity, which supposes their parity harmonious relationships. At the same time the catholicity as an ideal of accordance basing on conscience, compassion and awe serves as the source of the unity. The unity allows the sophy as the realization of the wisdom of nature creating and nature created to show itself. Common activity is the supreme goal and organization of human activity, presupposing formation of the noosphere.

The system of relationships suggested by Russian cosmists underlay the anthropocosmic paradigm of social 
development where co-operative relations, dialogue of man, nature and society are proclaimed. All that demands humanity revelation of its connection with nature, the whole Universe and the high level of culture.

According to the ideology of philosophers-cosmists the human is a substation, containing the essence of the Universe and being the main value of it. Russian thinkers believe that the main goal and meaning of a human life is a constant spiritual development and self-perfection. In their opinion it is possible for a man and the cosmos to be united on the assumption of new cosmic consciousness and supreme human spirituality development.

Thus human spirituality is considered to be the universal principle of human existence. Cosmists proclaim activity aiming in reaching one's prosperity and creating the necessary conditions for personal constructive abilities to be the supreme goal of spirituality. Considering spirituality to be a wealth of inner human world and cosmic expression of his soul, they believe it to play main and determinant role in human vital activity. Such approach of spiritual role consideration in human life radically differs from religion one (there the sphere of spiritual activity is believed to perform itself in the other world) and from West European philosophical approach according to which not human spirituality but his rationality is the main standard.

Russian cosmists are the first to point out the threat of global catastrophe as a result of disconnection between a man and the nature. Nowadays their warnings sound especially relevant due to imminent threat of ecological safety of the planet. The philosophers-cosmists' conclusion about the humanity being able to solve its problem by unification of all people and nations on spiritual and moral base and by Common action is considered to be a great contribution. The ideological doctrines of the Russian thinkers can serve as a guideline in searching the ways out of spiritual crisis not only for Russia, but also for the whole mankind. Exactly the underestimation of Russian cosmists' teachings leads to the present state of things when while studying there is not enough attention paid to human vital life organization with universal laws of the Nature and the Cosmos taking into account. As a result, nowadays global problems threatening human existence arise (Modern Philosophical Dictionary, 1996; Solovyov, B.C., 1990; and Lossky, H.O., 1991). Incomprehension of cosmic essence of a human being, loss of spirituality, professional partition of human's spiritual and creative potential turn him into an active executor of the Wildlife and a destructor of the integrity of the society (Tonenkova, M.M., 2002).

\section{Conclusion}

Russian religion thinkers' due in their answering many questions of imperishable significance. Even nowadays the problems they addressed have general appeal and are still of urgency. In our opinion, ideals, goals, values proclaimed by Russian thinkers must become an ideological base for Russian society spiritual development, rising generation upbringing. As a philosophical-methodological base of moral upbringing of young people one can use the following ideas, supposed by Russian religious thinkers:

1. A human as the greatest value of existence is a spiritual creature, possessing spiritual inner world which must be developed and perfected while living. The human wholeness is determined by the spiritual one.

2. The declaration of the primary role of the moral sphere in human life. Man's moral development occurs in creative aggregated communication with the other people. The moral meaning of human live realizing in social interaction consists in serving for Good and Justice.

\section{References}

Khomyakov, A.S., 1982. Poln.sobr.soch. In 8 tons. T1. M. pp. 382.

Modern Philosophical Dictionary., 1996. Ed. V.E. Kemerov. Moscow. Bishkek. Ekaterinburg.

The World Encyclopedia of Philosophy, 2001. Ed. A.A. Gritsanov. M., ACT, Mn., Harvest, modern literati.

Solovyov, B.C., 1988. Justification of the Good Moral Philosophy. Work in two volumes, Vol.1 M.

Solovyov, B.C. The first step to positive ethics // Works in 2 vol., Vol.2. M. 1988.

Solovyov, B.C., 1990. Collected works of 2 vol., Vol.1. M.

Yarkina, T.F., 1996. The problems of the human inner spiritual world and its formation in bioenergy environment. M.

Kireyevsky, I.V., 1996. Selected articles. M.

History of Education. 2-nd Part, 1998. XVII to the middle of XX century.: A manual for teaching universities / ed. A.I. Piskunov. M., "Sfera".

Kireyevsky, I.V., 1861. Complete Works. Vol. 1, Moscow.

Salnikov, V.P., Y.A. Sandulov, H.S. Gutseriev and I.I. Kalnoy, 2010. Philosophy for post-graduates: Textbook for higher educational institutions of Russian Interior Ministry adjuncts. 2nd edition / Ed. I.I. Kalnoy. St. Petersburg, St. Petersburg University of the Russian Interior Ministry. 
Zenkovsky, V.V., 1999. History of Russian Philosophy. In 2 volumes. Rostov-on-Don, Feniks.

Berdyaev, N.A., 1993. The Destiny of Man. M. 1999.

Frank, S.L., 1992. Spiritual foundations of society. M.

Lossky, N.O., 1994. Value and being // N.O. Lossky, God and the world's evil. M.

Karsavin, L.P., 1995. About personality/l Religious and philosophical writings. Vol.1, M.

Karsavin, L.P., 1995. Policy framework // World of Russia is Eurasia. M.

Novikov, A.I., 1998. History of Russian Philosophy of X-XX centuries. St.-Peterburg., Lan.

Lossky, H.O., 1991. The history of Russian philosophy. M.

Nekrasova, E.H., 1997. Living truth. Metaphysics of human existence in the Russian religious philosophy of the XX century. M., Martis.

Frank, S.L., 1956. Reality and people. Metaphysics of human existence. Paris.

Introduction to Russian philosophy., 1995. M.

Works of BIOGELGEOCHEM AS USSR, 1980. Vol.16, M.

Russian philosophy: Names. Teaching. Texts/Comp., 2001. Solncev N.V. Moscow, "INFRA-M", "Ves Mir".

Tonenkova, M.M., 2002. Space Foundations of Sociology of the spiritual life of the future of Russia // Social and humanitarian knowledge. №3.

Воденко, К.В., and Самыгин С.И., 2015. История религиозной философии. Ростов-на-Дону: Феникс, 252 с. 